\title{
MAGYAR „NEMZETKÖZI ÚJ VÁLLALATOK" \\ PIACVÁLASZTÁS ÉS A HÁLÓZATOK SZEREPE A KORAI NEMZETKÖZIESEDÉSBEN
}

\begin{abstract}
A magyar gazdaságban is egyre több az alapítása után gyorsan nemzetköziesedő vállalat. A cikk a „nemzetközi új vállalatok” elméletére támaszkodva vizsgálja vállalati interjúk alapján két kiválasztott iparágban a cégek nemzetköziesedésének jellemzőit. A szerzők egyrészt a külföldi piac kiválasztásának kritériumait elemzik, másrészt a hálózatok szerepét vizsgálják a nemzetköziesedés folyamatában. Eredményeik szerint a vizsgált vállalatok általában a legnagyobb fejlett piacokat veszik célba - igen sikeresen. A hálózatok szerepe meghatározó minden vizsgált esetben. Az alapító vagy tulajdonos személyes kapcsolatai minden vállalatnál fontos szerepet játszottak, különösen az első külföldi vevők „megnyerésében”. A szerzők ugyanakkor megkérdőjelezték a személyes hálózaton alapuló üzleti modell skálázhatóságát. Kutatásuk eredményei a vállalati menedzsment szempontjából a gyakorlatban is felhasználhatóak, mivel megmutatják, hogy a nemzetközi hálózatokban való részvétel intenzívebbé tétele fontos a vállalatnövekedés és nemzetköziesedés szempontjából.?
\end{abstract}

\section{Kulcsszavak: nemzetköziesedés, nemzetközi új vállalatok, külföldi piacra lépés}

Ö sszességében a magyar KKV-szektort alacsony szintủ nemzetköziesedés jellemzi. A KKV-k részesedése a magyar kivitelből egynegyed körül mozog (Mikesy, 2013). Más EU-tagországokkal összehasonlítva szembetünő a nemzetköziesedés alacsony, sőt időben romló szintje (European Commission, 2017). Ezért is különösen fontos és érdekes, hogy nemcsak a nemzetközi, hanem a magyar gazdaságban is nő a kicsiny, fiatal, sok esetben nemzetköziesedő vállalkozások száma. Egyre több olyan üzleti vagy újsághírrel, vagy cikkel találkozunk manapság, amely ezeknek a magyar vállalatoknak a létét jelzik és jellemzőit elemzik (lásd például Andrási és társai, 2009; Czakó - Könczöl, 2014; Békés - Muraközy, 2012; Némethné Pál, 2010; Mikesy, 2013; Szerb - Ulbert, 2009, vagy az ún. született globális (born global), vagy nemzetközi új vállalatok beazonosítását Magyarországon például Sass, 2012 vagy Szalavetz, 2015). Találunk ugyanilyen elemzéseket a kelet-közép-európai régió más országaira vonatkozóan is (lásd pl. Jarosinki, 2014; Zbierowski, 2014; Sliwinski - Sliwinska, 2014; Nowinski - Rialp, 2013; Kiss - Danis - Cavusgil, 2012; Lamotte - Colovic, 2015; Danik - Kowalik - Král, 2016; Vissak, 2007). Magyarország esetében Andrási és társai (2009) úgy találták, hogy a gyorsan növekvő, ún. gazellák az összes KKV kb. egyhatodát teszik ki. Más elemzések kiemelték, hogy ezek a vállalatok általában innovatívak, dinamikus, jelentős személyes kapcsolatrendszerrel rendelkező vezetőjük van (Papanek, 2012), míg megint más elemzések rámutattak, hogy e vállalatok egy része bár gyorsan növekszik, nem innovatívak, nem exportálnak, nem alkalmaznak magas színvonalú emberi tőkét, vezetőik nem különösebben iskolázottak vagy tapasztaltak, így maguk a cégek nem feltétlenül képesek tartós növekedést megvalósítani és versenyképes méretű közepes vagy nagyvállalattá válni (Szerb et al., 2017).

Ebben a cikkben a „nemzetközi új vállalatok” (international new ventures) koncepcióját és elemzési keretét használjuk, és két kiválaszott iparágban (biotechnológia és információs technológia) készített vállalati interjúk alapján vizsgálunk meg két propozíciót. Egyrészt a külföldi piac kiválasztásának kritériumait elemezzük, másrészt a hálózatok szerepét vizsgáljuk a nemzetköziesedés folyamatában. Cikkünk felépítése a következő. Először az elméleti hátteret és a szakirodalom legfontosabb eredményeit közöljük. Ezután ismertetjük kutatási kérdéseinket, az alkalmazott módszertant és a vállalati mintát. A következő részben ismertetjük kutatásunk eredményeit, majd az utolsó rész tartalmazza a következtetéseket.

\section{Az elméleti háttér és a szakirodalom eredményei}

A „nemzetközi új vállalatok” (international new venture - INV) elmélete több mint két évtizede jelent meg a szakirodalomban. Ezeket a szakirodalom olyan üzleti szervezetként határozza meg, amelynek megalapításától kezdve jelentős kompetitív előnye származik abból, hogy több országból származtat erőforrásokat és több országban is értékesíti termékeit (Oviatt - McDougall, 1994). Ezeknek a cégeknek a nemzetköziesedése gyors (McDougall - Shane - Oviatt, 1994; Sapienza et al., 2006; Matiusinaite - Sekliuckiene, 2015; Schwens - Kabst, 2009; Madsen, 2013; a kelet-közép-európai régióra: Jarosinski, 2013; Lamotte - Colovic, 2015; Zapletalová, 2015; Ciszewska-Mlinaric - Obloj - Wasowska, 2016; Musteen - Datta - Francis, 2014) más vállalatokéhoz viszonyítva,

${ }^{1}$ Sass Magdolna részvételét a kutatásban az OTKA/NKFIH (109294) támogatta. A cikk a Society and Economy c. folyóiratban angolul megjelenő tanulmány átdolgozott változata. 
amelyek fokozatosan nemzetköziesednek (lásd például az ún. Uppsala-modellt, amely a cégek fokozatos, lépcsőzetes nemzetköziesedését írja le: Johanson - Vahlne, 1977 vagy Eriksson et al., 1997; Vissak, 2003). A nemzetköziesedés a legtöbb esetben exporttevékenységet jelent (Fan - Phan, 2007); néhány esetben közvetlentőke-befektetés is történik. Az iparági sajátosságok fontos szerepet játszanak az INV-knél, nagymértékben befolyásolják a nemzetköziesedés folyamatát és a vállalatok stratégiaválasztását (Andersson - Evers - Kuivalainen, 2014). Ezt alátámasztja, hogy az INV-k általában olyan iparágakban koncentrálódnak, amelyeket magas technológiai intenzitás, niche (rés) technológia vagy tudásalapú tevékenységek jellemeznek (Autio - Sapienzia - Almeida, 2000; Oviatt - McDougall, 2005; Johnson, 2004; Welch, 2015). A nemzetköziesedési folyamat hasonlósága ellenére fontos hangsúlyozni Verbeke, Li és Goerzen (2009) eredményei alapján, hogy egyegy cég nemzetköziesedési folyamata erösen specifikus az adott vállalatra és környezetére nézve, így jelentősek lehetnek a különbségek a cégek nemzetköziesedési folyamatai között.

Elemzésünkben az INV-szakirodalom két fontos elemére támaszkodunk - kutatási kérdéseink alapján. Egyrészt, a globalizáció nyomán a külpiacok egyre hasonlóbbakká válnak egymáshoz, így a vállalatok, különösen azok, amelyek high-tech tevékenységeket végeznek, rögtön alapításuk után képesek lehetnek nemzetköziesedni a releváns réspiacokon (lásd pl. Jolly - Alahuta - Jeannet, 1992; Oviatt - McDougall, 1994; Knight - Cavusgil, 2004; Baum - Schwens - Kabst, 2011). A piacok növekvő hasonlósága, sőt homogenitása miatt nemzetköziesedésük kevesebb akadállyal néz szembe, mint a fokozatosan nemzetköziesedő vállalatoké (amelyek általában hagyományos iparágakban tevékenykednek). Így az INV-k gyorsan megjelennek a nemzetközi piacokon, ideértve a földrajzilag távolabb eső piacokat is, és véleményünk szerint, piacaik hasonlósága miatt, őket kevésbé befolyásolja a külkereskedelmi liberalizáció szintje a fokozatosan nemzetköziesedő cégekhez képest. A szakirodalom másik fontos vonulata a hálózatok szerepét elemzi a nemzetköziesedésben. Ez alapján a piacok a kapcsolatok hálózataként tekinthetők. Itt a vállalatok különféle és komplex kapcsolatok révén érintkeznek és kerülnek kapcsolatba egymással, és ezek a kapcsolatok lehetőséget adnak a tanulásra, további kapcsolatok létrehozására, a bizalom kiépítésére a felek között (Eriksson et al., 1997; Coviello - McAuley, 1999; Johanson - Vahlne, 2003 és 2011;Vissak, 2004). Egyes szerzők kiemelik a cégvezetők szerepét a hálózatokhoz kapcsolódásban, és végső soron e vállalatok sikerében (Papanek et al., 2010). Véleményünk szerint az INV-k, (iparági) sajátosságaik miatt, hajlandóbbak lehetnek a különféle hálózatokban való részvételre a fokozatosan nemzetköziesedő cégekhez képest, ami azután segíti nemzetköziesedésüket.

Elemzésünk a magyar INV-kre koncentrál. Az INV-k és született globális vállalatok jelenlétét a kelet-közép-európai régióban több cikk dokumentálja és elemzi. Az első tanulmányok fóleg azt húzták alá, hogy a posztszocialista gazdaságokban is léteznek ilyen vállalatok (Vissak, 2007; Sass, 2012). Nowinski és Rialp (2013) több régióspecifi- kus jellemzőjét írja le ezeknek a vállalatoknak. Hangsúlyozzák, hogy ezek a cégek nemcsak korlátozott pénzügyi erőforrásokkal rendelkeznek (Kiss et al., 2012), hanem viszonylag szűkösek a humán és szociális erőforrásaik is. Bemutatják továbbá, hogy van néhány régióspecifikus mozgatója korai nemzetköziesedésüknek, mint például belépési korlátok a hazai piacon versus nagy, fizetőképes piacok a (közeli) fejlett országokban. Aláhúzzák a hálózatok szerepét is: míg először a vállalkozók a hazai hálózataikra támaszkodnak, addig párhuzamosan a nemzetközi terjeszkedéssel, kiépítik a nemzetközi hálózataikat is. Egy másik érdekes régióspecifikus jellemző az erőforrásokkal takarékosan bánó stratégiák és müködési mód, amelyet a hiánygazdaságból örököltek, és ami a régióbeli cégek kompetitív előnyeinek részét képezheti vagy alapját adhatja (Ciszewska-Mlinaric - Obloj - Wasowska, 2016). Danik et al. (2016) hívta fel a figyelmet a régióbeli INV-k földrajzi célországainak, nemzetköziesedési kiterjedésének, innovációs hajlandóságának és innovációs területeinek eltéréseire más INV-kétől, cseh és lengyel vállalati példák alapján. Ebben a tekintetben a küldő és fogadó ország közötti bilaterális kapcsolatok erőssége és a diaszpóra szerepe is fontos lehet.

A magyar INV-ket vagy született globális vállalatokat vizsgáló tanulmányok kiemelik pl. azok jelenlétét az innovatív orvosimúszer-gyártásban (Sass, 2012). Ebben az ágazatban a sikeres és sok esetben gyors nemzetköziesedés alapja a vállalatok innovációs hajlandósága, ami részben a tervgazdaságban müködö, sikeres nagyvállalatok feldarabolásával létrejött kisvállalatok örökölt sajátossága, részben a területen erős innovációs aktivitást mutató magyar egyetemekhez köthetö. Szalavetz (2015) öt magyar vállalati esetet elemzett részletesen, és megvizsgálta, hogy milyen dinamikus képességek és készségek (dynamic capabilities) miatt tudtak sikeresen nemzetköziesedni.

\section{Kutatási propozíciók}

Cikkünkben az INV-k két fontos jellemzőjét vizsgáljuk meg magyar vállalati példák alapján.

\section{A nemzetköziesedés földrajzi kiterjedése}

A nemzetközi szakirodalom hangsúlyozza, hogy az INV-k gyorsan nemzetköziesednek, eltérö földrajzi kiterjedéssel. Így például a szakirodalom egyik meghatározó cikke szerint, amely egyébként bevezette az INV-k fogalmát is (Oviatt - McDougall, 1994), négyféle INV különböztethető meg, amelyek esetében a nemzetköziesedés földrajzi kiterjedése is jelentősen eltér egymástól. Az „új nemzetközi piaclétrehozók” esetében a cégek legfontosabb tulajdonosi előnyét az jelenti, hogy képesek az egyes országok piacai közötti egyensúlytalanságokat beazonosítani és olyan helyeken is piacokat létrehozni a termékük számára, ahol azok azelőtt nem léteztek. Ezek az INV-típusok nagymértékben függenek a célpiacuktól, így a nemzetköziesedés földrajzi kiterjedését gyakorlatilag előre meghatározzák a potenciális piac jellemzői. Ezek lehetnek ,export/import start-upok” vagy „,multinacionális kereskedők" - az említett szerzők kategóriáit használva. A ,földrajzilag fókuszált start-up”-ok, mint ahogy nevük 
is jelzi, egy bizonyos régió vagy ország speciális igényeit elégítik ki, külföldi források felhasználásával. Ebben az esetben is meghatározóak a megcélzott piac jellemzői. A negyedik kategória, a „globális start-up” esetében sokkal kevésbé meghatározott a vállalat számára a nemzetközi terjeszkedés földrajzi iránya, földrajzilag sokkal kevésbé korlátozott a nemzetközi terjeszkedés. Véleményünk szerint az utóbbi kategória vállalatai sokkal inkább vannak jelen a növekvő globális kereslettel rendelkező innovatív ágazatokban, mint amilyenek az általunk vizsgált biotechnológiai és információs technológiai ágazatok is.

Ahogyan említettük, az INV-k leginkább a technológiaintenzív ágazatokban vannak jelen. A high-tech termékek általában „globálisak”, kevés igény van lokális adaptációra (Andersson, 2004) és jelentős mértékủ a standardizáció, így gyakorlatilag rögtön eladhatók bármelyik országban, ahol fizetőképes kereslet mutatkozik irántuk, és ahol (potenciális) vásárlói vannak (Bell, 1995). Ezt a folyamatot nagymértékben elősegítette a globalizáció, ami a világon fellelhető nemzeti piacokat egymáshoz egyre inkább hasonlóvá tette. Így e termékek esetében az ún. pszichikai távolság jelentősen lecsökkent (Evers, 2010). Ezen felül az új technológiai fejlesztések, az internet mint szállítási csatorna egyre erőteljesebb megjelenése lehetővé tette az új iparágak számára, hogy termékeiket földrajzilag távol eső régiókban, országokban is értékesítsék, ami tovább csökkentette a nemzetközi müködés földrajzi korlátozottságát. Ezen felül iparágaik és termékeik sajátosságai miatt az INV-k általában viszonylag kicsiny réspiacokat „,támadnak” és földrajzilag szétszórt vezető piacaik (lead market) vannak a világban. Figyelik fogyasztói célcsoportjaikat és erősen fogyasztóorientáltak (Rialp et al., 2005). Így azt mondhatjuk, földrajzilag nem korlátozottak, miközben fogyasztóikat proaktívan követik. Néhány esetben ez kényszerként jelentkezik: mivel a réspiacok általában nagyon kicsinyek, ezért el kell érniük egy értékesítési (ideértve az exportot is) küszöbértéket ahhoz, hogy nyereségesek legyenek, és ehhez sok esetben a hazai piac nem elegendő. Így például a hazai piac kicsinysége szignifikáns magyarázó változó egy INV nemzetköziesedésében Fan és Phan (2007) tanulmányában. Továbbá a réspiacokon a viszonylag alacsony szintű verseny és az a törekvés, hogy minél inkább kihasználják azt a speciális tudást, amin az INV tulajdonosi előnye nyugszik, arra sarkallja a céget, hogy gyorsan nemzetköziesedjen minden egyes elérhető piacon. Ennek eredményeképpen az INV-k esetében a nemzetköziesedés földrajzi terjedelme általában sokkal tágabb, mint más vállalatok esetében.

Hogyan határozhatjuk meg, mérhetjük és vethetjük össze a nemzetköziesedés földrajzi kiterjedését az INV-k esetében? A küldő és fogadó országok távolsága (a belépési mód mellett) a vállalat nemzetköziesedési folyamatának egyik legfontosabb dimenziója (Jones - Coviello, 2005). A vállalat földrajzi „,terjedelme” mérhető külföldi piacainak számával, földrajzi megoszlásával, szórtságával és különbözőségével (Hashai, 2011).

A fentiek alapján első propozíciónk a vizsgált INV-k nemzetköziesedésének földrajzi kiterjedéséről fogalmaz meg állítást:
A tudásintenzív iparágakban müködő magyar INV-k számára a nemzetköziesedés során az elsődleges célpiacok a magasan fejlett országok réspiacai.

\section{A nemzetköziesedés hálózatos megközelítései}

Szervezeti és politikatudományi megközelítéseken alapul a nemzetköziesedés hálózatos felfogása. A vállalatok közötti kapcsolatok fontosságát hangsúlyozzák, melyek eredményeként egy bonyolult kapcsolati hálózat jön létre. Ezek a kapcsolatok többféle formát ölthetnek, lehetnek szociális, gazdasági, jogi vagy technológiai információk „cseréi” a vállalatok között. Alapozódhatnak a vállalat menedzserei közötti személyes kapcsolatokra. Lehetnek formálisak vagy informálisak. Már a vállalat alapítása előtt is létezhetnek, mint az alapító személyes kapcsolati hálójának részei.

Egy elméleti cikkben Vissak (2004) összegzi a nemzetköziesedés hálózati felfogásával kapcsolatos nézeteit, többek között azt hangsúlyozva, hogy ez a megközelítés releváns abban a tekintetben, hogy meghaladja a hagyományos nemzetköziesedési modelleket, jól írja le az üzleti világot és környezetet, és a megközelítés alkalmas arra, hogy megmagyarázza a külföldi piacok kiválasztását és azt a folyamatot, ahogyan a nemzetköziesedéshez szükséges források megszerezhetők a hálózati kapcsolatok segítségével.

Oviatt és McDougall (1995) is hangsúlyozzák, hogy az INV-k erős nemzetközi üzleti hálózattal rendelkeznek. Más elméleti és empirikus tanulmányok is aláhúzzák a hálózatok fontosságát abban, hogy képessé teszik az újonnan alapított vállalatokat a nemzetköziesedésre (lásd pl. Bell, 1995; Fillis, 2002; vagy Rialp - Rialp - Knight, 2005). Coviello és Munro (1995) bemutatta, hogy a hálózatos kapcsolatok meghatározó jelentőségűek abban, hogy felgyorsítsák az új nemzetközi vállalatok új külföldi piacokra történő belépését. Ezen felül a hálózati kapcsolatok fontosak a vállalat növekedése szempontjából is, és befolyásolják a nemzetköziesedés alakulását is a külpiacok és a belépési mód kiválasztása területén. Továbbá Chetty és Blankenburg Holm (2000) elemzik a szervesen kifejlődő hálózatok fontosságát, és bemutatják, hogy ez megmagyarázza annak dinamikáját, hogy a cégek hogyan működnek együtt hálózati partnereikkel, hogy nemzetközi piacaikat kiterjesszék, integrálják. Következtetésük szerint az ilyen interakciókban való részvétel segíti a vállalatot abban, hogy új lehetőségekhez és tudáshoz jusson, és hogy élvezze a megosztott források elönyeit. Chetty és CampbellHunt (2004) szerint a gyorsan nemzetköziesedö, született globális cégek hálózati stratégiája ,agresszív”, ellentétben a lassabban és később nemzetköziesedő vállalatokkal. Ugyanakkor a hálózatok korlátokat is jelentenek a vállalatmüködés szempontjából. Johanson és Vahlne (2011) szerint a nemzetközi üzleti környezetben müködő cégeknek tiszteletben kell tartaniuk hálózati partnereik érdekeit, és így váratlan lépésekre (és ellenlépésekre) is késznek kell lenniük.

Habár jelentős a hálózatosodás nemzetköziesedésben betöltött fontos szerepéröl szóló irodalom, meg kell említenünk, hogy néhány elemzés szerint elhanyagolható a 
hálózatok szerepe a gyorsan nemzetköziesedő INV-k és született globális vállalatok esetében (Kalinic - Forza, 2012). Rasmussen, Madsen és Evangelista (2001) szerint néhány INV esetében az alapító nem vesz részt a nemzetköziesedés elött hálózatokban.

A kelet-közép-európai régió esetében az empirikus tanulmányok eredményei a hálózatok szerepéröl a következők. Daszkiewicz (2014) több mint 200 nemzetköziesedett lengyel vállalatot vizsgált meg egy felmérés keretében 2013-14-ben. Azt akarta megtudni, van-e statisztikailag kimutatható kapcsolat a nemzetköziesedés motivációi és a hálózatokban való részvétel között. Eredményei szerint létezik ilyen kapcsolat Dunning (1993) nemzetköziesedési motivációs tipológiája alapján. Ugyanakkor a kapcsolat nem volt szignifikáns az OECD (OECD, 1997a, 1997b) motivációs tipológiája szerint. Azt találta még, hogy a hálózatokban való részvétel kapcsolatban állt a cég külpiacokról felhalmozott tudásával és aktuálisan követett stratégiájával. Tíz magyar KKV vizsgálata alapján Czakó és Könczöl (2014) arra a következtetésre jutott, hogy kutatási módszerük korlátai ellenére bizonyítható, hogy az 1990-ben vagy az után alapított vállalatok a Johanson és Vahlne (2009) által leírt, hálózatalapú nemzetköziesedés jellemzőit mutatják.

A fentiek alapján az elméleti és gyakorlati irodalom nem kínál egyértelmü bizonyítékot a hálózati részvétel szerepére a kelet-közép-európai INV-k nemzetköziesedésében. Második propozíciónk ezzel a dilemmával foglalkozik:

A (széles értelemben vett) hálózatokban való részvétel fontos szerepet játszik a tudásintenzív iparágakban müködő magyar INV-k számára.

\section{Módszertan, vállalati minta}

Az alapítókkal folytatott, félig-strukturált, kérdőívvel vezetett interjúk alapján készítettünk anonim vállalati esettanulmányokat. Az információs technológiai (IT) és biotechnológiai ágazatokban kerestünk olyan vállalatokat, amelyek megfelelnek az INV kritériumainak, vagyis már megalapításuk idején felmerült a nemzetköziesedés célja és a megalapítás után nem sokkal valamilyen módon nem- zetköziesedtek is. Ezt a módszertani megközelítést gyakran alkalmazzák a vállalatok nemzetköziesedésének, az INV-knek vagy a született globális cégeknek a vizsgálatában (Vissak, 2010). (A magyar szakirodalomban lásd pl. Sass, 2012; Czakó - Könczöl, 2014 vagy Szalavetz, 2015.) Mintánk természetesen nem reprezentatív, de az ágazati szükítés azt szolgálta, hogy nagyobb valószínüséggel találjuk meg a magyar INV-ket.

Módszertanunk előnye, hogy a vizsgált vállalatok nemzetköziesedésének folyamatáról és működéséről részletes információval rendelkezünk. Hátránya ugyanakkor, hogy a minta nem reprezentatív, és így eredményeink általánosíthatósága korlátozott. Az 1. táblázatban mutatjuk be a mintánkban részt vevő vállalatokat. Hat vállalattal készült interjú, ezek közül kettő biotechnológiai, négy pedig információs technológiai vállalat. A hatból öt céget kevesebb, mint öt éve alapítottak. Mindegyikük egy éven belül nemzetköziesedett.

\section{Elemzési eredmények}

Számos kérdés merült fel a félig strukturált interjúkban, ezzel együtt elemzésünk a két propozícióra összpontosult. Az alábbi elemzési eredmények propozícióink bizonyos elemeire reflektálnak, és lehetőséget adtak számunkra, hogy a témánkkal kapcsolatos ismereteinket több szempontból finomítsuk.

\section{Piacválasztás külföldön}

Elsőként az volt a célunk, hogy jobban megértsük, illetve esetlegesen finomítsuk első propozíciónk elemeinek relatív súlyát: „A tudásintenzív iparágakban müködő magyar INV-k számára a nemzetköziesedés során az elsődleges célpiacok a magasan fejlett országok réspiacai”.

Mintánkba tudásintenzív iparágak vállalatai kerültek, ami megmagyarázni látszik a tényt, hogy eredményeink összhangban vannak a propozícióban foglaltakkal, egyetlen vállalat kivételével (egy IT-vállalat): ez a cég Magyarországon és három szomszédos országban nyújt szolgáltatást. Minden más vállalat esetében a fejlett országokba való export meghatározó részét adja a teljes értékesítésnek. Ennek a kivételt képező cégnek a stratégiája arra irá-

1. táblázat A vállalati minta jellemzői

\begin{tabular}{|c|c|c|c|c|c|c|}
\hline Vállalat & Ágazat & Központ & \begin{tabular}{|l} 
Foglalkoztatottak \\
száma \\
Magyarországon
\end{tabular} & Alapítás éve & $\begin{array}{l}\text { A nemzetköziesedés } \\
\text { kezdete }\end{array}$ & $\begin{array}{l}\text { Az első } \\
\text { nemzetköziesedési } \\
\text { lépés }\end{array}$ \\
\hline A & biotechnológia & Budapest & 35 & 1990 & 1990 & export \\
\hline B & $\begin{array}{l}\text { biotechnológia } \\
\text { (magas } \\
\text { IT-tartalommal) }\end{array}$ & Budapest & 17 & 2011 & 2012 & $\begin{array}{l}\text { együttmüködés } \\
\text { USA-beli } \\
\text { egyetemmel }\end{array}$ \\
\hline $\mathrm{C}$ & IT & Budapest & 6 & 2015 & 2015 & export \\
\hline $\mathrm{D}$ & IT & Budapest & 20 & 2014 & 2014 & export \\
\hline $\mathrm{E}$ & IT & Budapest & 7 (a felvásárlásig) & $\begin{array}{l}2012 \\
\text { (eladták 2015-ben) }\end{array}$ & 2013 & $\begin{array}{l}\text { export, } \\
\text { helyi képviselők/ } \\
\text { értékesítők }\end{array}$ \\
\hline $\mathrm{F}$ & IT & Budapest & 10 (a felvásárlásig) & $\begin{array}{l}2012 \\
\text { (eladták 2014-ben) }\end{array}$ & 2012 & export \\
\hline
\end{tabular}

Forrás: a szerzők összeállítása a vállalati interjúk és a vállalati mérlegadatok alapján 
nyult, hogy lemásolja a globálisan sikeres üzleti modellt, és alkalmazza a régióban, ahol elsőként próbálkoztak ezzel, így gyorsan terjeszkedtek. Nem meglepő módon néhány évvel később megvásárolta őket az iparág egyik nagy globális szereplöje.

A jellemző ok, amiért a nagy és fejlett piacokat választják a korán nemzetköziesedő vállalatok az, hogy a termékek árai és a szolgáltatási díjak magasabbak ezekben az országokban, míg a magyar bérek viszonylag alacsonyak. Egy további ok, amiért egy INV a legnagyobb fejlett piacokat célozza az, hogy jobban skálázható az üzlet a nagy piacokon, és a vállalkozás nagyobb növekedési lehetőségei a nemzetközi terjeszkedést finanszírozó befektetők szemében vonzóbbá teszik a vállalatot.

„A vállalatot a világpiacra hoztuk létre: nem a magyar piacra értékesítünk - ott csak egy lehetséges vevő lenne a piac korlátozott mérete miatt. Velük jó személyes és tudományos kapcsolatuk van, de nincs piaci kapcsolatuk." (Interjú a B vállalatnál)

Mindezzel összefüggésben a mintánkban szereplő B vállalat nagymértékű hasonlóságot mutat a "globális startup" jelenséggel, amelyet Oviatt és McDougall fogalmazott meg (1994). A következő interjúkivonatok alapján a D vállalat is ebbe a kategóriába tartozik.

„Mi nem a magyar piacra hoztuk létre a vállalatot. Nem vagyunk elégedettek a hazai üzleti kultúrával, és a piac nem kellően jövedelmező. A szoftverfejlesztés nem lokációspecifikus üzlet amúgy sem.” (Interjú a D vállalatnál)

Interjúalanyaink továbbá arról számoltak be nekünk, hogy egyre csökken a különbség a hazai és a nemzetközi elvárások szintjében, ami a technológia-színvonalban korábban megvolt a fejlett piacok és Magyarország között. Ebből következően a szolgáltatások szintje, amelynek megfelelően az INV-k teljesítenek, viszonylag hasonló, miközben a vásárlóerő és a szabadon felhasználható jövedelem jóval magasabb a nagy fejlett piacokon. Ha ebből a szemszögből nézzük, nem meglepő, hogy a legtöbb INV ezeket a piacokat választja már nemzetköziesedésének korai szakaszában is.

A korai szakaszukban lévő INV-vállalatok többnyire egy réspiacot „támadnak” a fejlett piacokon, mert egy rés eredményesebben célozható meg testre szabással és online marketinggel a ,big data" technológiára alapozva. Továbbá amennyiben a marketing pontosabban célozza meg a kívánt szegmenst, kevesebb zaj lesz a marketingkommunikációban, miközben általános tendencia, hogy a fogyasztók túlontúl nagy mennyiségü üzenettel szembesülnek napi szinten.

„A vállalat talált egy réspiacot és arra jött létre, hogy ennek a célpiacnak szoftvert fejlesszen. A szoftver segítségével számos vevővállalattal építettek ki kapcsolatot, így a piac helyzetét jobban meg tudták ítélni ezen a területen. Erre alapozva a vállalat termelési tevékenységbe fogott és tudományos együttmüködést kezdeményezett amerikai egyetemekkel.” (Interjú a B vállalatnál)

A nem (csupán) a nagy piacokat, hanem a kisebb országokat is megcélzó INV-vállalatok más típusú előnyökkel és hátrányokkal szembesülnek. A helyi szabályozási környezet sokszor kihívást jelent mind annak megértése, mind az ahhoz való alkalmazkodás vonatkozásában, illetve származhatnak ebből olyan korlátozások, amelyek zökkenőket visznek a fejlett piacokra kialakított üzleti müködésbe. Kulturális kihívások is felmerülhetnek, noha interjúalanyaink ezt kevéssé érezték súlyosnak, mivel körültekintően választották ki külföldi célpiacaikat. Mindemellett felhívták a figyelmet arra, hogy a kevésbé fejlett, viszonylag új és kevésbé szabályozott piacok olyan üzleti lehetőségeket is rejthetnek, amelyek túlmutatnak a fejlett, jobban szabályozott piacok lehetőségein.

A kelet-közép-európai piacokon aktív vállalatoknál interjúalanyaink megjegyezték, hogy jelentős szinergia származhat a régió különböző országaiban való müködésből. A kulturális minták hasonlóak, így az egyik országban bevált üzleti modell kisebb változtatásokkal alkalmazható a szomszédos országokban. Felmerülhet annak a lehetősége is, hogy ne országonként külön, hanem egy központból müködjön az adminisztráció és a támogató funkciók egy része.

„Szinergia volt a kulturális hasonlóságokból eredően a régió négy országában, amelyben piacra léptünk. Voltak kinti kapcsolataink, ismertük már a kultúrát, és bemutattak minket helyi üzleti partnereknek. A magyar üzleti modellünk jól skálázható volt, s ez kritikusnak bizonyult, mivel a hazai piac nem volt elég nagy a fenntartható üzemmérethez. Mindemellett mind a négy országban eltérő szabályozások voltak érvényben, és párhuzamosan kellett kiépítenünk folyamatainkat. Legalábbis az elején." (Interjú az F vállalatnál)

Közvetlenül rákérdeztünk arra az alapvetö kérdésre, hogy milyen tényezőket fontoltak meg a célpiacok kiválasztásakor a nemzetköziesedés korai szakaszában. Bár vizsgálódásunk alapvetően kvalitatív természetü, a legjellemzőbb válaszokat egy rövid listában összegeztük. Így tehát a legfontosabb döntési tényezők: piacméret (lehetséges bevétel nagysága), a piac érettsége (növekedési potenciál), földrajzi távolság, kulturális távolság, helyi kapcsolat vagy képviselő megléte (a személyes hálózatokhoz való hozzáférés), illetve a verseny kiélezettsége (elsők voltak-e a piacon). Ebböl arra következtettünk, hogy nincsenek meglepetések a listán, ahhoz képest, amik megszokott megfontolásoknak számítanak a meglévő nemzetközi vállalatgazdaságtani irodalom alapján.

\section{A hálózatok szerepe a nemzetköziesedésben}

Másik fókuszpontunkat a második propozíciónkban fogalmaztuk meg: "A (széles értelemben vett) hálózatokban való részvétel fontos szerepet játszik a tudásintenzív iparágakban müködő magyar INV-k számára." Célunk volt alaposabban megérteni ezt a jelenséget, illetve tovább pontosítani állításunkat az elemzés eredménye alapján.

Teljes egyetértést tapasztaltunk abban a tekintetben, hogy az alapítók személyes kapcsolatrendszere és tudása kulcsfontosságú volt az első ügyfelek elnyerésében. Interjúalanyaink cégei csak azt követően fejlesztették ki a termékeiket, hogy megpróbálták a megcélzott piacokat megérteni, és ez a piaci tudásuk, a szükséges termékkel kapcsolatos tudásuk a régióban meglévő személyes kap- 
csolataikban gyökerezett. Az interjúk során hallottuk, hogy az egyes piacokon kezdetben meglévő bizalomhiány leküzdése szinte megoldhatatlan kihívást jelenthet, amennyiben nincsenek személyes kapcsolatok a bizalom elnyeréséhez. E bizalom segítheti az INV-k termékeinek piachoz illesztését a kezdetekkor. A bizalom megszerzése mellett a piachoz való hozzáférést is segíti az a piaci tudás, amely az alapítóktól és helyi kapcsolataiktól származik.

„A privatizációt követően tevékenységünk nem keltette fel az új tulajdonos érdeklődését, ezért hagyta, hogy kiváljunk. Az alaptőkét saját pénzből adtuk össze, létrehoztuk a céget, két igazgató beugrott egy Ladába, és meglátogatta azokat a nyugat-európai gyógyszercégeket, akikről tudtuk, hogy érdekelheti őket a termékünk és tevékenységünk. Három üzleti kapcsolattal jöttünk haza - a többi pedig ezután következett." (Interjú az A vállalatnál)

A személyes kapcsolatokra épülő üzleti modell skálázhatóságát több interjúalanyunk megkérdőjelezte. A mintánkban szereplő INV-vállalatok mindannyian tervezték tevékenységük felfuttatását a külföldi piacokon, már fejlődésük korai fázisában. Ebből kifolyólag felmerült a kérdés, hogy az üzleti modell nem függ-e túlzottan az alapítóktól. Míg az alapítók személyes kapcsolatai, úgy tünik, stratégiai eszközt jelentettek a vállalat első ügyfeleinek megszerzésében, ha az értékesítés ezt követően is az alapítók kapcsolatrendszerére épült, hamar a kapacitáskorlát problémájába ütközött a cég. Minden ember csak egy bizonyos mértékig képes egy kiterjedt ügyfélkapcsolati hálózatot müködtetni, ezért egy jól szervezett értékesítési és ügyfélszolgálati csapatot építettek ki a legtöbb vállalatnál, akikkel beszéltünk.

„Vannak személyes kapcsolataim az új piacokon, amelyeket megcéloztunk. Ez ugyanakkor nem skálázható, ebből nem származhat kellően sok új ügyfél. Az új kapcsolatok a korábbi ügyleteinkből származnak, a kockázati tőkés befektetőinktől, konferenciákról... Ez egy folyamat: a vállalat egyre kevésbé függ az alapítóitól.” (Interjú a D vállalatnál)

Általános jelenségként tapasztaltuk az interjúk alapján, hogy a termék vagy az üzleti koncepció eredeti ötlete jellemzően egy külföldi minta hazai adaptációjából származott vagy magának az ötletnek az érvényességét benchmarking segítségével ellenőrizte a vállalkozó. Az általunk vizsgált vállalatok alapítói kivétel nélkül vagy tanultak, vagy dolgoztak már külföldön, a vállalat alapítását megelőzően. Külföldi tartózkodásuk alatt szereztek benyomásokat többféle megoldásról és üzleti modellről az adott területen, és ennek hatására kezdtek gondolkodni, hogyan tudnák az elképzelést saját hazájukban megvalósítani. Egy kevésbé közvetlen módja a nemzetközi benchmarkingnak szintén felmerült az interjúkban. Ebben az esetben az alapító fejében megszületett egy üzlet ötlete, és mielőtt formálisan nekiállt volna megszervezni a vállalkozást, külföldi összehasonlító példákat keresett, amelyek segítségével tesztelte az ötlet létjogosultságát. Még ha a közvetlen alkalmazása egy külföldön fogant ötletnek nem is volt mindig lehetséges, a külföldi összehasonlító példák hasznos viszonyítási alapnak számítottak, amelyek segítségével a vállalkozás irányban tartható volt, a külföldi vállalatok sikertörténetei alapján.
Az alapítók, miként fentebb említettük, tanultak vagy dolgoztak már külföldön a magyar vállalat megalapítását megelőzően. Ez nemcsak azért volt hasznos, mert az ötlet érvényessége vizsgálható volt, hanem mert egyúttal építették nemzetközi kapcsolatrendszerüket, amely később az első külföldi értékesítés során létfontosságúnak bizonyult. Úgy tünik, a nemzetközi kapcsolatrendszer kiépítésének nincs más hatásos módja, mint a személyes látogatások a tanulmányok, vagy a munkatapasztalatok megszerzésének korai szakaszában.

Megkérdeztük, milyen konkrét módon építhetők a kapcsolatok, és miként hasznosíthatók az INV-vállalatok számára. Egyes interjúalanyaink hangsúlyozták a „hallgatás" képességének fontosságát. Egy nemzetközi hálózatba való beágyazódásunk, mondták, sokkal kevésbé szól arról, hogy magunkat vagy termékünket reklámozzuk, és sokkal inkább arról, hogy megpróbálunk odafigyelni a helyi véleményvezérekre. Tudjuk, hogy a bizalom milyen fontos a kapcsolatrendszerünk későbbi hasznosításában, márpedig a bizalom elnyerése jóval könnyebb, ha a vállalkozó tisztelettel és figyelemmel fordul a beszélgetésekben felmerülő témák iránt, semmint ha saját maga próbálná tematizálni a társalgást.

Hálózatot építeni mindemellett egy folyamatos feladatot jelent. Interjúalanyaink megerősítették, hogy korai üzleti sikereik révén további kapcsolatokat tudtak kiépíteni a külföldi piacokon. A hálózati integráció és az üzleti siker közötti kapcsolatot kétirányúnak fogják fel, azaz nemcsak kezdeti kapcsolatrendszerük segítette az első üzleti sikerek elérését, de a folyamatos üzleti siker segített nekik mélyebben integrálódni a hálózatokba, sőt újabb piacokra belépni más hálózatok segítségével.

Az interjúkban arra is rákérdeztünk, hogy miként tudtak a vállalkozók a számukra érdekes hálózatokba hatékonyan és eredményesen beépülni. Többen hangsúlyozták a „bevonzó marketing” (inbound marketing) jelentőségét, amellyel az alapítók növelni tudták hitelességüket a vállalkozás nemzetköziesedésének korai szakaszában. A bevonzó marketing célja, hogy felkeltse egy téma iránt érdeklődők figyelmét, többnyire az interneten keresztül, s így növeli a forgalmat a vállalkozó honlapján vagy blogján. Amint egy érzékelhető nagyságú olvasói kör létrejön, jellemző, hogy a vállalkozót meghívják az általa megcélzott hálózatba való csatlakozásra. A konferenciák a hálózat tagjainak elsődleges találkozóhelyei, ezért az itt történő részvétel gyakran fontos mérföldkövet jelent a vállalkozó hálózati integrációjának folyamatában.

„Az inbound marketing egy létra, amit meg lehet mászni. Megosztasz valamilyen tartalmat, írsz egy blogposztot és bekapcsolódsz beszélgetésekbe, azzal, hogy figyelsz másokra. Kapcsolatokat építesz ki, mert lehet, hogy lesz belőlük valami, ami később fontos lehet." (Interjú a $\mathrm{C}$ vállalatnál)

A válaszok alapján megértettük, hogy a külföldi piacokon a helyi kulturális adottságokat célszerü megismernie az INV vezetőinek, annak érdekében, hogy érdemi esélyük legyen a nemzetközi sikerre. A kultúra összetett jelenség, ezért kihívást jelent és időigényes a megismerése, így arra is rákérdeztünk, milyen módon lehet a kulturá- 
lis tanulást elősegíteni. Két alapvető választ kaptunk. Az egyik lehetőség a kultúra megismerésére, nem meglepő módon az, hogy a vállalat alapítói személyes látogatásokat tesznek a megcélzott külföldi országban. Minden általunk megvizsgált esetben ez része volt a nemzetköziesedési folyamatnak, különösen a piacra lépés korai fázisában. A másik lehetőség, amely felmerült, az a helyi vállalati képviselő alkalmazása volt, ideális esetben még azelőtt, hogy a vállalat piacra lépése megtörtént volna. Nagy kihívást jelenthet egy megbízható és jó képességű helyi képviselő felkutatása, ezért az INV-vállalatok célpiacválasztásában szempontként merülhet fel az egyes országokban a helyi kapcsolattartó megléte vagy annak hiánya.

Érdekesnek találtuk, hogy egyes interjúalanyaink megemlítették, hogy nem voltak magukra hagyva, amikor egyes új külpiacokra akartak kilépni, vagy egy kapcsolati hálóba szerettek volna integrálódni. A ,startupper közösség" aktívan tudott segíteni, hogy találkozhassanak hasonlóan gondolkodó vállalkozókkal, akik igyekeznek egymást segíteni, kölcsönösségi alapon. Bemutatni a másikat egy potenciális vevőnek, vagy egy helyi kapcsolattartónak például jellemző módja a segítségnek. A többi vállalkozó szívesen nyújt ilyen segítséget, mert arra számítanak, hogy ök is támogatásban részesülhetnek valamikor, ha szükségük lesz rá a jövőben.

Jellemző módja egy INV-vállalat korai exporttevékenységének, hogy a leendő külföldi ügyfél helyi képviselöjével veszi fel a cég a kapcsolatot először. Ezt könnyebben megvalósítható megoldásnak tartják a vállalatvezetők, mint amilyen kihívást a leendő ügyfél külföldi vállalatközpontjával való közvetlen kapcsolatfelvétel lenne. Amint a cég termékei sikert aratnak külföldön, a külföldi hálózatokba való közvetlen integrálódás már reálisabb feltételekkel megvalósítható.

Egyik interjúalanyunk érdekes kifejezést használt, amikor „névleges kapcsolatokról” beszélt. Arra utalt ezzel, hogy vannak ismerősei, akik elvileg elérhetök, ha valamilyen segítségre lenne szüksége tölük. Ugyanakkor, amikor ténylegesen felmerül a lehetőség, hogy a segítségre szükség lenne, akkor úgy tünik, nem érdekli őket igazán a dolog, és puszta gesztusok megtételén túl más nem várható tőlük. A kérés, hogy hívják fel néhány barátjukat, vagy mutassanak be minket egy leendő ügyfélnek már több annál, mint amit készek megtenni értünk. Emiatt interjúalanyunk aláhúzta, hogy ennél tartalmasabb személyes kapcsolatrendszerre van szükség, mert a „névleges kapcsolatok” nem lesznek segítőkészek szükség idején.

Néhány vállalkozó tovább ment és arra a következtetésre jutott, hogy a személyes kapcsolatok építésének igazi értelme egy INV-vállalat számára abban rejlik, hogy lehetőségeket nyitnak meg új üzletfelekkel való találkozókhoz. Egy vállalkozó, aki eltökélten keresi annak a lehetőségét, hogy a hálózat valamely tagját új üzletfélnek mutathassa be, eséllyel számíthat arra, hogy ő is hasonló segítséget fog kapni valakitől a hálózatból, és ezzel saját nemzetköziesedése felgyorsul.

„Ez egy mézesbödön, amely vonzza a méheket. Milyen lehetőségeket tudsz adni mások számára? A saját kapcso- lati hálód oly módon fog épülni, ahogy értéket tudsz adni mások számára.” (Interjú a C vállalatnál).

\section{Következtetések}

Hat magyar INV-vállalat esettanulmányára épülő empirikus vizsgálatunk során feltártuk e vállalatok piacválasztásának szempontjait, valamint a hálózatok szerepét nemzetköziesedésükben. A nemzetköziesedés földrajzi kiterjedésének vonatkozásában a vizsgálati mintánkban szereplő vállalatok jellemző módon a legnagyobb, fejlett külföldi piacokat célozták világszerte. Emellett voltak kivételnek számító esetek, amikor fokozatosabb nemzetköziesedés volt tapasztalható. Ebben a tekintetben vizsgálatunk eredményei megegyeznek a nemzetközi szakirodaloméval, jelezve, hogy a magyar INV-k hasonlóan viselkednek, mint nemzetközi társaik.

Azért a nagy fejlett piacokat választották a cégek, mert ezeken a piacokon magasabbak az árak, míg a magyar munkaerö költsége alacsonyabb. Emellett megfigyelhetö, hogy csökken a különbség a hazai és a fejlettebb piacok között a nyújtott szolgáltatások technológiai minőségében. Ebből következik, hogy a nemzetköziesedés könnyebb, egyúttal szükségszerü választás a kis réspiacokon müködő magyar INV-vállalatok számára. Világszerte megcélozni egyes réspiacokat esetenként könnyebb lehet, mert itt kisebb a zaj az online marketingben.

Másrészt azt is megtudtuk interjúalanyainktól, hogy kihívást jelent sok kisebb országban szolgáltatást nyújtani, mert a helyi szabályozáshoz nem ritkán nehéz igazodni. Ugyanakkor réspiacokon, illetve új és ezért kevésbé szabályozott piacokon ez a kihívás kisebb lehet, ami indokolja a magyar INV-k piacválasztását. Vizsgálatunk másik eredménye, hogy a nemzetköziesedés célpiacai könnyen bővíthetők, mivel szinergia jön létre a vállalat különböző országokbeli működésében, amennyiben a helyi kulturális minták hasonlóak (pl. a kelet-közép-európai régióban vagy bizonyos fejlett piacokon).

A hálózatok szerepe a nemzetköziesedésben, a mintánkba került vállalatok szereplői szerint meghatározó jelentőségű, minden vizsgált esetben. Az alapítók személyes kapcsolatrendszerét (és tudását) hangsúlyozták, különösen az első megrendelök elnyerésénél. Ez alátámasztja a hálózatoknak a KKV-k nemzetköziesedésében gyakorolt jelentős szerepét kiemelő külföldi szakirodalom eredményeit. Ugyanakkor mintánk esetében kimutatható, hogy a személyes kapcsolatrendszerre épülö üzleti modell skálázhatósága kérdéses - ezen a területen nem találkoztunk nemzetközi vizsgálati eredményekkel.

Az eredeti ötlet, amelyböl a vállalkozás indult, jellemzően nemzetközi minták helyi alkalmazására épül, illetve az ötlet nemzetközi mintákkal történő igazolására. A magyar INV-vállalatok alapítói jellemző módon külföldön tanultak vagy dolgoztak a vállalat létrehozását megelőzően. Többnyire a nagy fejlett piacokon szereztek tapasztalatokat és széles körü (szakmai és személyes) kapcsolatokat építettek ki fontosabb külföldi vállalatokkal vagy egyetemekkel, aláhúzva a „hálózat” - a személyes kapcsolatok - fontosságát. 
A hálózatok tényleges fejlesztésének mikéntje vonatkozásában válaszadóink hangsúlyozták, hogy a hálózatépítés egy időben változó, fejlődő folyamat, mivel az üzleti siker újabb kapcsolatokat hoz. Ezen túlmenően a „,bevonzó marketing" erősíti az INV-vállalatok hitelességét, mert tudásintenzív iparágakban ez a tevékenység lehetővé teszi, hogy a vállalatok bemutatkozzanak új hálózatoknak. A ,startupper közösség” pedig gyakran segítséget nyújt e hálózat tagjainak, kölcsönösségi alapon, hogy bemutatkozhassanak külföldi piacokon, a lehetséges vevőknek vagy partnereknek. Így eredményeink részben bemutatják azokat a mechanizmusokat, amelyek révén „hólabdaszerủen" bővülhet a nemzetköziesedést segítő hálózat.

Sajátos, általunk nem várt eredményként értékeljük, hogy a kutatási mintánkban is látható módon a sikeresen nemzetköziesedő, innovatív hazai cégeket nem ritkán külföldi cégek felvásárolják. Elgondolkodtató, hogy a hazai ökoszisztéma ennek alapján megfelelően tudja-e támogatni azt, hogy nagy globális cégek jöjjenek létre Magyarországon. További kutatást igényelne annak vizsgálata, hogy a hazai „globálisnak született" vállalatok nem csupán „mini-globális cégeknek” tekinthetők-e.

Eredményeink hozzátesznek az INV-vállalatok piacválasztásának és a nemzetköziesedés hálózati megközelítésének irodalmához, azon keresztül, hogy feltártuk a sikeres tudásintenzív magyar vállalatok nemzetköziesedési mintáit. Következtetéseink alapját képezhetik olyan jövőbeli kutatásoknak, amelyek fókuszáltabb kérdés mentén, nagyobb magyar mintán, illetve esetlegesen nemzetközi összehasonlító kutatás keretében vizsgálják a jelenséget. Tekintettel a vállalkozások sajátos történeti hátterére, amely régiónkban jellemzö, további kutatások igazolhatják a régióspecifikus nemzetköziesedési mintázatok létét az INV-vállalatok vonatkozásában.

Eredményeink felhívják a figyelmet a tudásintenzív INV-vállalatok számára célszerű piacválasztási lehetöségekre, amelyek elemzésünk szerint elsősorban a nagy fejlett piacok egyes részpiacaira irányulnak, különösen akkor, ha az alapítók rendelkeznek elözetes tapasztalattal az adott országban és iparágban. Vizsgálatunk rámutatott arra, hogy döntő szerepe van a személyes kapcsolatoknak a megcélzott piacokon, ezért a magyar INV-vállalatoknak érdemes növelni a nemzetközi közösségekben való beágyazottságukat, amelyek a vállalatok növekedését támogathatják.

A jövőbeli lehetséges kutatási területek vonatkozásában feltártuk, hogy két propozíciónk nagyobb mintán való vizsgálata, csakúgy, mint további, régióbeli országok INV-vállalatainak bevonása, valamint további kapcsolódó témák elemzése nagy potenciállal bíró kutatási irányok lehetnek. Ilyen további téma lehet például annak a vezetői szerepnek a vizsgálata, hogy az alapítók miként tudják kollégáikat bevonni a kapcsolatépítésbe, illetve a munkaeröhiány esetlegesen milyen módon csökkenthető a hálózatok segítségével. Az INV-vállalatok nemzetköziesedésének szakaszait és érettségét szintén érdemes lenne közelebbröl szemügyre venni.

Makroszinten is vannak további lehetséges kutatási területek. Két IT-vállalatot, akik a mintánkba kerültek, időközben eladták külföldi vállalatoknak, s ez felhívhatja a figyelmet a nagyvállalatok túlsúlyára a társadalmi-gazdasági innovációs ökoszisztémában, valamint arra, hogy a pénzügyi szektor kevéssé hatékony szereplője a reálgazdaság finanszírozásának. Szintén makroszintű kérdésként vizsgálható az ún. középvállalati csapda a kelet-közép-európai piacokon, témánkhoz kapcsolódóan azon keresztül, hogy elemezzük az INV-vállalatok jelenléte, fejlettebb piacokra való költözése vagy külföldi cégek által történő felvásárlásának összefüggéseit.

\section{Felhasznált irodalom}

Andersson, S. (2004): Internationalization in different industrial contexts. Journal of Business Venturing, 19(6), p. 851-875.

Andersson, S. - Evers, N. - Kuivalainen, O. (2014): International new ventures: rapid internationalization across different industry contexts. European Business Review, 26(5), p. 390 - 405.

Andrási Z. - Borsi B. - Farkas L. - Némethné Pál K. - Papanek G. -Viszt E. (2009): A mikro-, kis- és közepes vállalatok növekedésének feltételei. Budapest: GKI Gazdaságkutató Zrt.

Baum, M. - Schwens, C. - Kabst, R. (2011): A Typology of International New Ventures: Empirical Evidence from High-Technology Industries. Journal of Small Business Management, 49(3), p. 305-330.

Autio, E. - Sapienza, H. J. - Almeida, J. G. (2000): Effects of age at entry, knowledge intensity, and imitability on international growth. Academy of Management Journal, 43(5), p. 909-924.

Békés, G. - Muraközy, B. (2012): Magyar gazellák. A gyors növekedésű vállalatok jellemzői és kialakulásuk elemzése. Közgazdasági Szemle, 59(3), p. 233262.

Bell, J. (1995): The internationalization of small computer software firms: A further challenge to "stage" theories. European Journal of Marketing, 29(8), p. 60-75.

Chetty, S. - Blankenburg Holm, D. (2000): Internationalisation of small to medium-sized manufacturing firms: a network approach. International Business Review, 9(1), p. 77-93.

Chetty, S. - Campbell-Hunt, C. (2004): A Strategic Approach to Internationalization: A Traditional Versus a "Born-Global" Approach. Journal of International Marketing, 12(1), p. 57-81.

Ciszewska-Mlinaric, M. - Obloj, K. - Wasowska, A. (2016): Effectuation and causation: Two decision-making logics of INVs at the early stage of growth and internationalisation. Journal for East European Management Studies, 21(3), p. 275-297.

Coviello, N. E. - McAuley, A. (1999): Internationalisation and the smaller firm: A review of contemporary empirical research. Management International Review, 39(3), p. 223-256.

Coviello, N. E. - Munro, H. J. (1995): Growing the entrepreneurial firm: networking for international market development. European Journal of Marketing, 29(7), p. 49-61. 
Coviello, N. E. - Munro, H. (1997): Network relationships and the internationalisation process of small software firms. International Business Review, 6(4), p. 361-386.

Czakó, E. - Könczöl, E. (2014): Critical Success Factors of Export Excellence and Policy Implications: The Case of Hungarian Small and Medium-Sized Enterprises. In: Gubik, A. S. - Wach, K. (eds): International Entrepreneurship and Corporate Growth in Visegrad Countries. Miskolc, Hungary: University of Miskolc, p. 69-84.

Danik L. - Kowalik, I. - Král, P. (2016): A comparative analysis of Polish and Czech international new ventures. Central European Business Review, 5 (2), p. 57-73.

Daszkiewicz, N. (2014): Internationalisation of Firms through Networks - Empirical Evidence from Poland. In: Gubik, A. S. - Wach, K. (eds): International Entrepreneurship and Corporate Growth in Visegrad Countries. Miskolc, Hungary: University of Miskolc, p. 57-68.

Dunning, J. H. (1993): Multinational enterprises and the global economy. Wokingham, Berkshire: Addison Wesley

Eriksson, K. - Johanson, J. - Majkgård, A. - Sharma, D. (1997): Experiential knowledge and cost in the internationalization process. Journal of International Business Studies, 28, p. 337-360.

Evers, N. (2010): Factors influencing the internationalisation of new ventures in the Irish aquaculture industry: An exploratory study. Journal of International Entrepreneurship, 8 (4), p. 392-416.

European Commission (2017): 2017 SBA Fact Sheet, Hungary. https://ec.europa.eu/growth/smes/business-friendly-environment/performance-review_hu\#sba-factsheets

Fan, T. - Phan, P. (2007): International new ventures: Revisiting the influences behind the "born-global" firm. Journal of International Business Studies, 38, p. 11131131.

Fillis, I. (2002): The internationalization process of the craft microenterprise. Journal of Developmental Entrepreneurship, 7(1), p. 25-43.

Hashai, N. (2011): Sequencing the expansion of geographic scope and foreign operations by "born global" firms. Journal of International Business Studies, 42(8), p. 995-1015.

Jarosiński, M. (2013): Contemporary models of Polish firms' internationalization - literature and research review. Journal of Economics and Management, 13, p. 57-65.

Jarosiński, M. (2014): Characteristics of Polish Firms' Internationalisation Processes. In: Knezevic, B. - Wach, K. (eds): International Business from the Central European Perspective. Zagreb, Croatia: University of Zagreb - Faculty of Economics and Business, p. 43-52.

Johanson, J. - Vahlne, J. E. (1977): The internationalization process of the firm - a model of knowledge development and increasing foreign market commitments. Journal of International Business Studies, 8(1), p. 23 -32.

Johanson, J. - Vahlne, J. E. (2003): Business relationship learning and commitment in the internationalization process. Journal of International Entrepreneurship, 1, p. 83-101.

Johanson, J. - Vahlne, J. E. (2009): The Uppsala Internationalisation Process Model Revisited. From Liability of Foreignness to Liability of Outsidership. Journal of International Business Studies, 40(9), p. 1411-1431.

Johanson, J. - Vahlne, J. E. (2011): Markets as networks: implications for strategy-making. Journal of the Academy of Marketing Science, 39, p. 484-491.

Johnson, J. E. (2004): Factors Influencing the Early Internationalization of High Technology Start-ups: US and UK Evidence. Journal of International Entrepreneurship, 2, p. 139-154.

Jolly, V. K. - Alahuta, M. - Jeannet, J.-P. (1992): Challenging the incumbents: How high-technology startups compete globally. Journal of Strategic Change, 1(2), p. 71-82.

Jones, M. V. - Coviello, N. E. (2005): Internationalization: Conceptualizing an entrepreneurial process of behavior in time. Journal of International Business Studies, 36(3), p. 284-303.

Kalinic, I. - Forza, C. (2012): Rapid internationalization of traditional SMEs: Between gradualist models and born globals. International Business Review, 21, p. 694-707.

Kiss, A. N. - Danis, W. M. - Cavusgil, S. T. (2012): International Entrepreneurship Research in Emerging Economies: A Critical Review and Research Agenda. Journal of Business Venturing, 27 (2), p. 266-190.

Knight, G. A. - Cavusgil, S. T. (2004): Innovation, Organizational Capabilities, and the Born-Global Firm. Journal of International Business Studies, 35(2), p. 124-141.

Lamotte, O. - Colovic, A. (2015): Early Internationalization of New Ventures From Emerging Countries: The Case of Transition Economies. Management, 18(1), p. 8-30.

McDougall, P. P. - Shane, S. - Oviatt, B. M. (1994): Explaining the formation of international new ventures: The limits of theories from international business research. Journal of Business Venturing, 9(6), p. 469-487.

Madsen, T. K. (2013): Early and rapidly internationalizing ventures: Similarities and differences between classifications based on the original international new venture and born global literatures. Journal of International Entrepreneurship, 11, p. 65-79.

Matiusinaite, A. - Sekliuckiene, J. (2015): Factors determining early internationalization of entrepreneurial SMEs: Theoretical approach. International Journal of Business and Economic Sciences Applied Research, 8(3), p. 21-32.

Mikesy Á. (2013): A magyarországi mikro-, kis- és középvállalatok nemzetköziesedése és a külföldi értékesítést nehezítő akadályok. Külgazdaság, LVII. évfolyam, 2013. január-február, p. 92-120.

Musteen, M. - Datta, D. K. - Francis, J. (2014): Early internationalization by firms in transition economies into developed markets: the role of international networks. Global Strategy Journal, 4, p. 221-237.

Némethné Pál K. (2010): Hol szökellnek a magyar gazellák? A dinamikusan növekvő kis- és középvál- 
lalatok néhány jellemzője. Vezetéstudomány, 41, p. $32-44$.

Nowiński, W. - Rialp, A. (2013): Drivers and strategies of international new ventures from a Central European transition economy. Journal for East European Management Studies, 18(2), p. 191-231.

OECD (1997a): Globalisation and Small and Medium Enterprises, vol. 1: Synthesis Report

$O E C D$ (1997b): Globalisation and Small and Medium Enterprises, vol. 2: Country Reports

Oviatt, B. M. - McDougall, P. P. (1994): Toward a theory of international new ventures. Journal of International Business Studies, 25(1), p. 45 -64.

Oviatt, B. M. - McDougall, P. P. (1995): Global start-ups: Entrepreneurs on a worldwide stage. Academy of Management Executive, 9(2), p. 30 - 44.

Oviatt, B. M. - McDougall, P. P. (2005): Defining International Entrepreneurship and Modeling the Speed of Internationalization. Entrepreneurship Theory and Practice. 29(5), p. 537-553.

Papanek G. (2010): A gyorsan növekvő magyar kis- és középvállalatok a gazdaság motorjai. Közgazdasági Szemle, 77(4), p. 354-370.

Papanek G. (2012) A regionális kapcsolatok jelentősége a KKV-k fejlődésében. In: Bajmócy Zoltán - Lengyel Imre - Málovics György (szerk.) (2012): Regionális innovációs képesség, versenyképesség és fenntarthatóság. Szeged: JATEPress, p. 195-206.

Rasmussen, E. S. - Madsen, T. K. - Evangelista, F. (2001): The founding of the born global company in Denmark and Australia: Sensemaking and Networking. Asia Pacific Journal of Marketing and Logistics, 13(3), p. 75 $-107$.

Rialp, A. - Rialp, J. - Knight, G. A. (2005): The phenomenon of early internationalizing firms: what do we know after a decade (1993-2003) of scientific inquiry? International Business Review, 14(2), p. 147-166.

Rialp, A. - Rialp, J. - Urbano, D. - Vaillant, Y. (2005): The born-global phenomenon: A comparative case study research. Journal of International Entrepreneurship, 3(2), p. 133-171.

Sapienza, H. - Autio, E. - George, G. - Zahra, S. A. (2006): A Capabilities Perspective on the Effects of Early Internationalization on Firm Survival and Growth. Academy of Management Review, 31(4), p. 914-933.

Sass, M. (2012): Internationalisation of innovative SMEs in the Hungarian medical precision instruments industry. Post-Communist Economies, 24(3), p. 365-382.

Schwens, C. -Kabst, R. (2009): Early internationalization: A transaction cost economics and structural embed- dedness perspective. Journal of International Entrepreneurship, 7, p. 323-340.

Śliwiński, R. - Śliwińska, M. (2014): Growth in the Polish Fast Growing Enterprises on Foreign Markets and Its Limitations. In: Knezevic, B. - Wach, K. (eds): International Business from the Central European Perspective. Zagreb, Croatia: University of Zagreb - Faculty of Economics and Business, p. 67-82.

Szalavetz, A. (2015): A dynamic capabilities perspective of high-growth firms: organizational aspects. International Journal of Management and Economics, 48, p. 45-62.

Szerb L. - Komlósi É. - Varga A. (2017): Gyors növekedésủ vállalatok Magyarországon. Közgazdasági Szemle, 64(5), p. 476-506.

Szerb L. - Ulbert, J. (2009): The examination of the competitiveness in the Hungarian SME sector: A firm level analysis. Acta Polytechnica Hungarica, 6(3), p. 105123.

Verbeke, A. - Li, L. - Goerzen, A. (2009): Toward more effective research on the multinationality-performance relationship. Management International Review, 49(2), p. $149-162$.

Vissak, T. (2003): The Internationalization of foreign-owned enterprises in Estonia: an extended network perspective. PhD dissertation. Tartu, Finland: Tartu University Press

Vissak, T. (2004): The importance and limitations of the network approach to internationalization. 20th IMPconference in Copenhagen, Denmark, https://impgroup.org/uploads/papers/4607.pdf Accessed: 4 July 2017.

Vissak, T. (2007): The Emergence and Success Factors of Fast Internationalizers. Journal of East-West Business, 13(1), p. 11-33.

Vissak, T. (2010): Recommendations for Using the Case Study Method in International Business Research. The Qualitative Report, 15(2), p. 370-388.

Welch, L. S. (2015): The emergence of a knowledge-based theory of internationalisation. Prometheus, 33(4), p. 361-374.

Zapletalová, S. (2015): Models of Czech companies' internationalization. Journal of International Entrepreneurship, 13, p. 153-168.

Zbierowski, P. (2014): Determinants of Early Internationalization - Empirical Evidence from Global Entrepreneurship Monitor. In: Knezevic, B. - Wach, K. (eds): International Business from the Central European Perspective. Zagreb, Croatia: University of Zagreb Faculty of Economics and Business, p. 27-42. 